
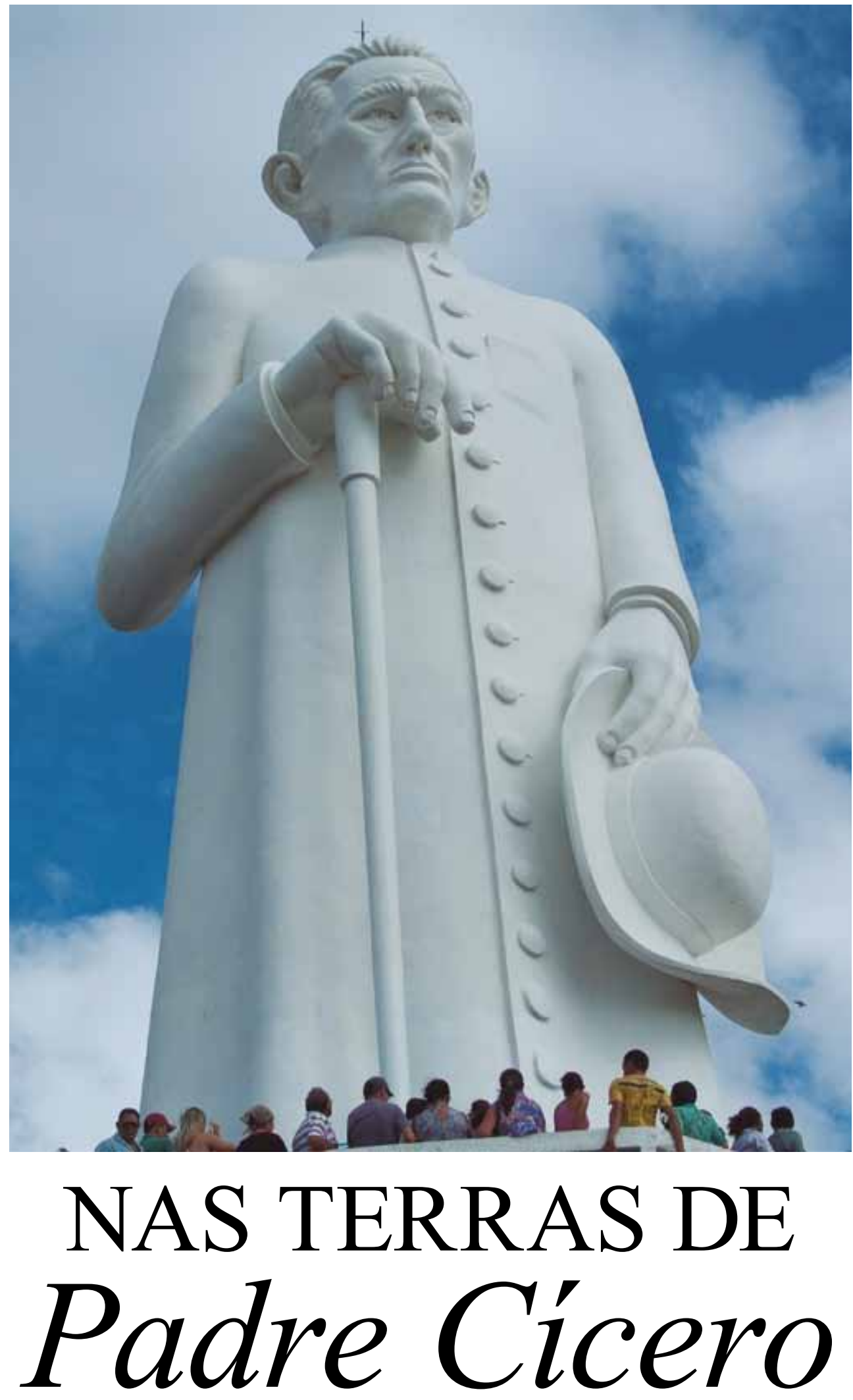

Atílio Avancini 


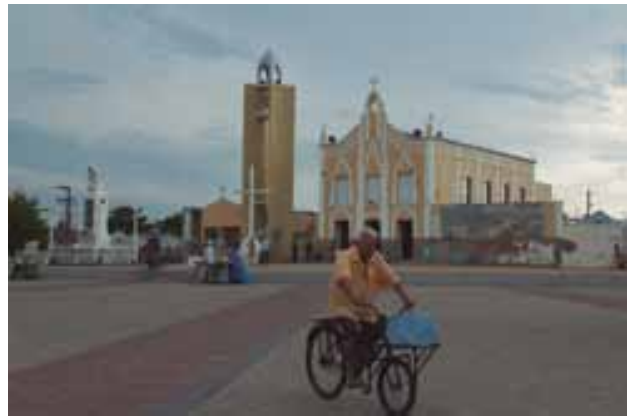

ATÍLIO AVANCINI é fotógrafo, professor da ECAUSP e autor de, entre outros, Entre Gueixas e Samurais (Edusp/Imprensa Oficial).

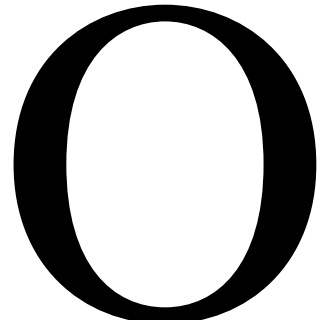

dia amanhece no alto da colina de Juazeiro do Norte (CE) entre fogos de artifício. É inverno no sertão. Nuvens brancas e cinzas flutuam sobre o fundo azul. Águas despencam do céu, promovendo o verde e amenizando o calor. Nesse cenário agreste, desponta a escultura monumental a homenagear o Padre Cícero. De lá, a postura ereta da estátua parece velar por tudo e por todos. De fato, sua presença parece viva. Padre Cícero é fala mítica que revela o que os seres humanos têm em comum, criando harmonia com a vida cotidiana do povo que lhe pede a bênção.

O itinerário, para ir a pé ao monumento Padre Cícero - "o patriarca do Nordeste" -, parece causar a impressão de estar concebido na escala do romeiro. Como ordenam o percurso ascendente e o calor escaldante, os peregrinos devem trajar roupas leves e chapéu para enfrentar no mínimo uma hora e meia de caminhada. No trajeto, há imagens de Jesus em pequenos santuários, lembrando os estágios da Paixão de Cristo. Recomenda-se sair bem cedo ou se render ao transporte público ou privado.
$\mathrm{O}$ efeito de estar diante do monumento é impactante, sua tonalidade branca ganha luminescência própria, inspirando plenitude como um sopro de origem celeste. Esculpida por Armando Lacerda e idealizada pelo prefeito de Juazeiro do Norte, Mauro Sampaio, em 1969, a obra de arte em concreto armado pesa 500 toneladas e possui altura de $25 \mathrm{~m}$. Construída em plena ditadura militar pelo general Emílio Garrastazu Médici, sintetiza o primeiro marco público para uma transformação social da região.

Juazeiro do Norte, com população em torno de 250 mil habitantes (IBGE, 2012),

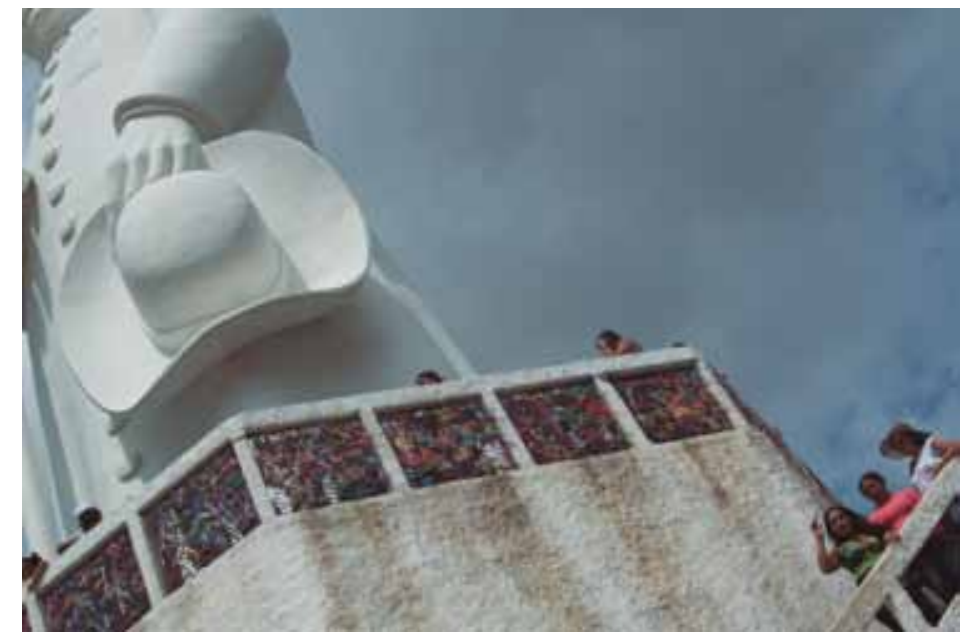



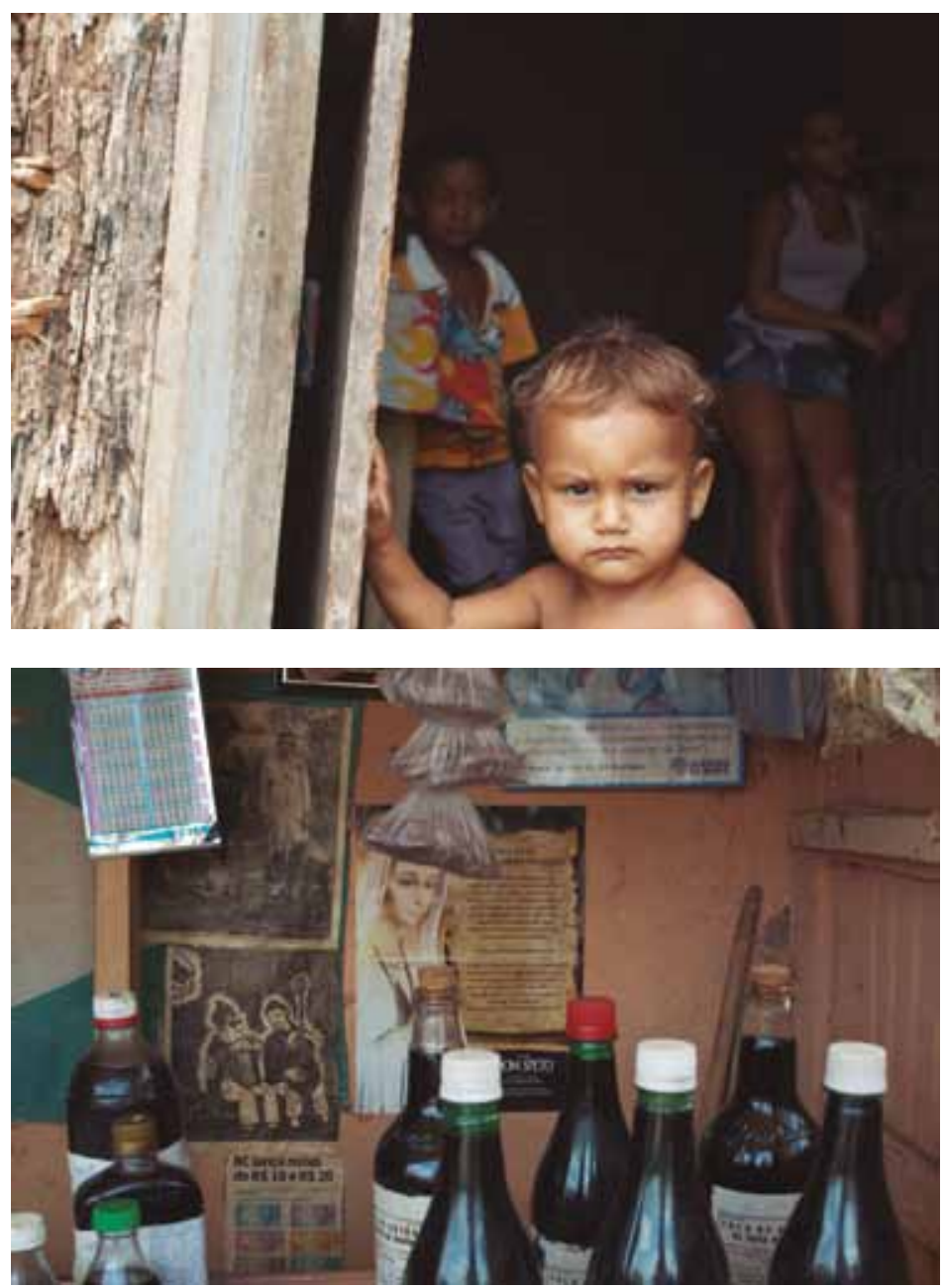

A cidadania como "não lugar" é impulsionada pelo turismo, evidenciando uma forte tendência para a indústria, o comércio, a agropecuária e a formação universitária. O crescimento da cidade dissemina escolas superiores, moderniza as relações de trabalho, alarga os atores sociais, diversifica as trocas, e cria a superação de servos da terra por assalariados urbanos com contratos e direitos. Mesmo com o continuísmo do baixo rendimento das escolas públicas - mas com

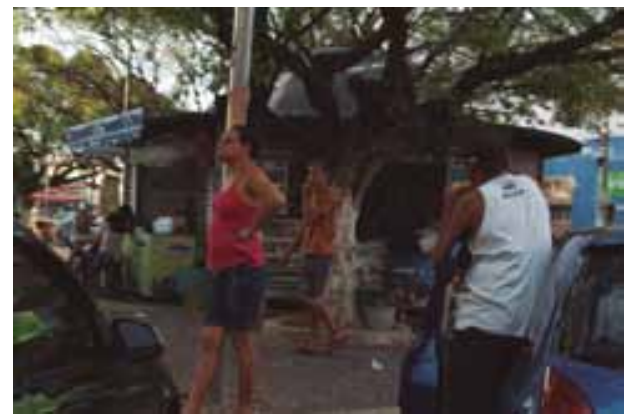

o diferencial financeiro do Bolsa Família pode-se afirmar que o horizonte de cidadania começa timidamente a despontar.

Mas o efeito dessa nova condição é ainda muito pouco. A violência urbana, como linguagem estrutural do passado, se faz presente nos pedintes, ambulantes, bancadas com objetos à venda e calçadas cobertas por lixo. Ou seja, a estátua do Padre Cícero confronta a indústria da seca, refletida pelo caráter oligárquico e populista da política nordestina, com o capitalismo incipiente.

A cidadania, portanto, torna-se um estado de "não lugar", ou seja, lugar virtual do acontecimento. A riqueza cultural do Nordeste e sua insistente ecologia da seca criam o paradoxo do sertanejo. O jornalista Gutemberg Medeiros comenta a imagem do homem estarrecido (de camisa branca e chapéu preto), diante da encruzilhada do tempo insinuada pela televisão:

"O sertanejo vê a construção de uma tradição perdida, o seu fantasma, mediado por um dispositivo. Ele vê o que não existe com traços do que existiu pela alta definição da televisão. A imagem na tela é uma falsificação: um artifício exclusivamente para diversão, baseado em outro tempo e entretenimento, o dos cangaceiros. Ao fundo da imagem da cantora está uma figura não hermética, de fácil tradução colada no tempo e no espaço do que se assiste: a imagem estilizada de Padre Cícero. Na bancada com os DVDs repousam pilhas de imagens furtadas de outros, que furtaram de outros, na vertigem da era da reprodutibilidade técnica que a dimensão digital só acelera. A única imagem que não é invenção é a própria fotografia”.

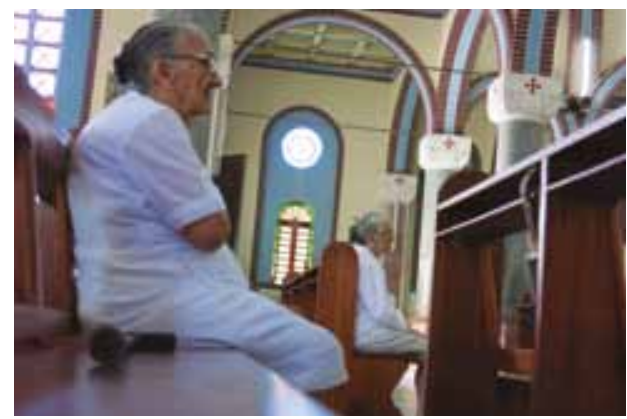




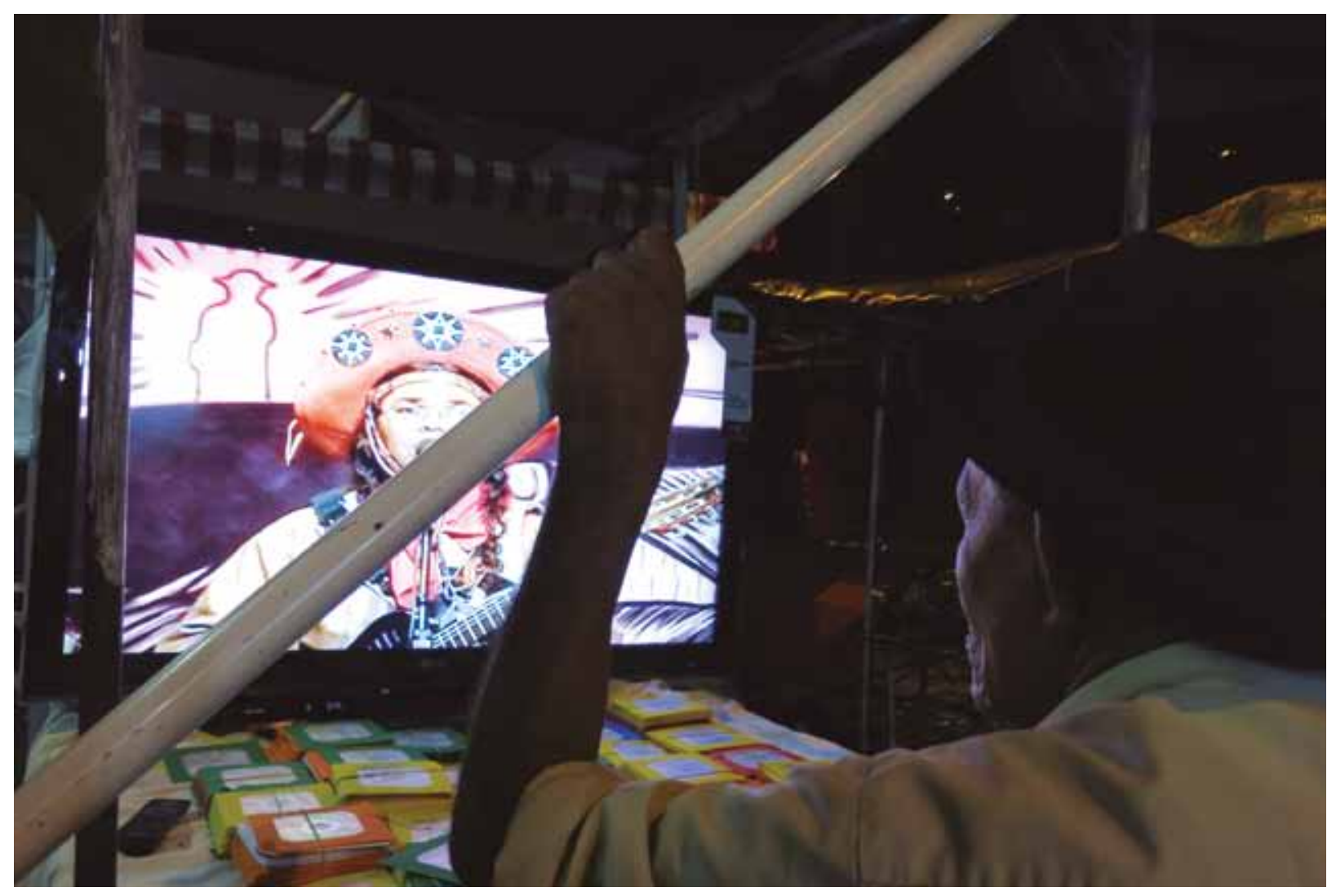

\section{PASTOR HUMILDE}

Os romeiros se inscrevem em um discurso de exaltação da fé, incorporada à linguagem característica do sertão. Tudo parece concorrer para consolidar a imagem de uma sociedade sofrida e carente diante da força divina. Os presentes se reconhecem pelo silêncio estampado no rosto, pois vem da simplicidade o gesto natural para receber as bênçãos do local sagrado. Vale ressaltar que a Colina do Horto Santo Sepulcro foi antigo retiro e morada de Padre Cícero - o amplo espaço arquitetônico define diferentes perspectivas entre o grandioso monumento, a capela, o museu e uma igreja de concreto armado a ser concluída em 2014.

O público de fiéis, na maioria de sertanejos, parece alheio à ideia do que foram o coronelismo e a sua estrutura social e psicológica, embora a pulverização dos recursos econômicos faça com que os romeiros sejam contínuos personagens residuais da partilha. No pequeno museu, a nostalgia mesclada de religião e política oferece um universo iconográfico reduzido às fotografias na parede, às esculturas e aos ex-votos (objetos no formato de partes do corpo humano, que teriam sido curadas, oferecidos pela graça alcançada). Assim, a memória e o passado emergem pela sobreposição da história oral, imagética e escrita de Padre Cícero como suporte regulador de equilíbrios.

\section{Estimular a produção independente da comunicação não garante ação educativa e democrática}

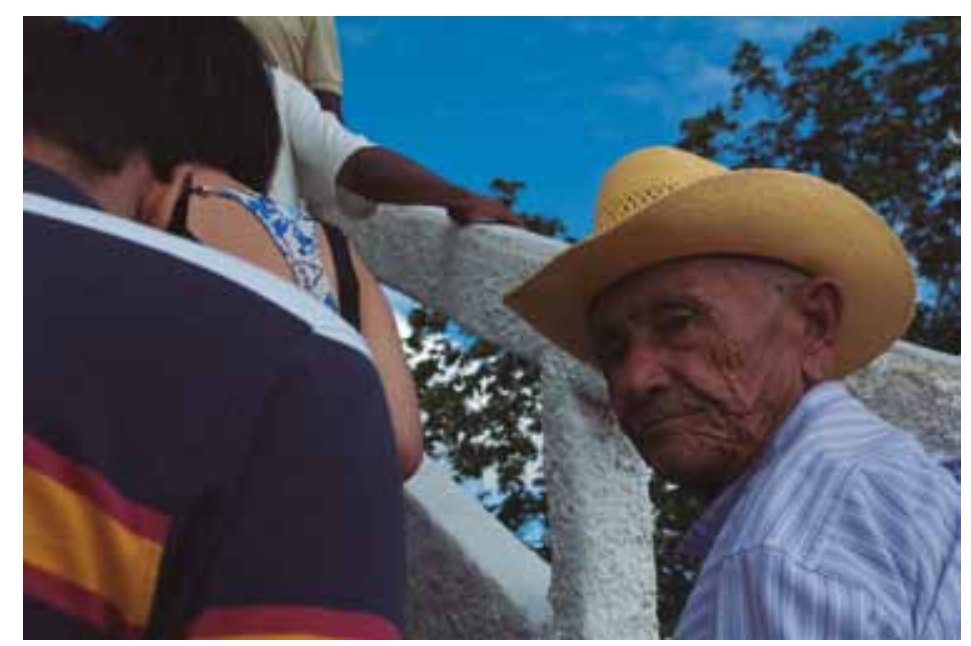




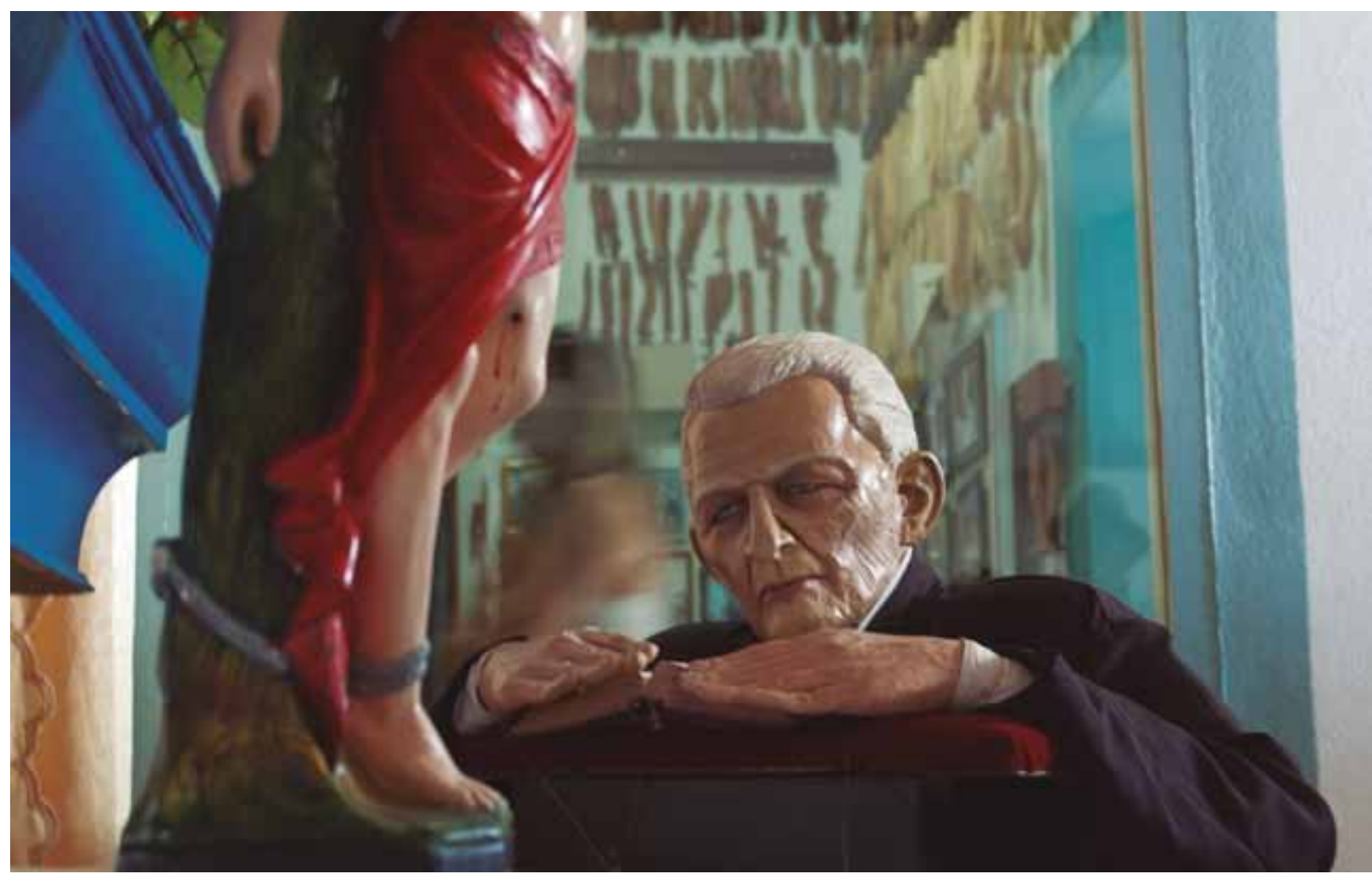

Imagens ensinam a lidar com

os prazeres e dissabores
Dona Mundinha (Raimunda Tavares da Silva), nascida na cidade vizinha do Crato, narra a sensação das representações de $\mathrm{Pa}$ dre Cícero no museu, que traz imagens em madeira e cera do cotidiano do líder carismático, trajando sempre a sua batina preta. Confeccionadas pelos escultores locais, a função das representações é mostrar ao público cenas de Padre Cícero no trabalho, na sala de jantar, nas orações e bênçãos e até no descanso deitado sobre a rede. Dona

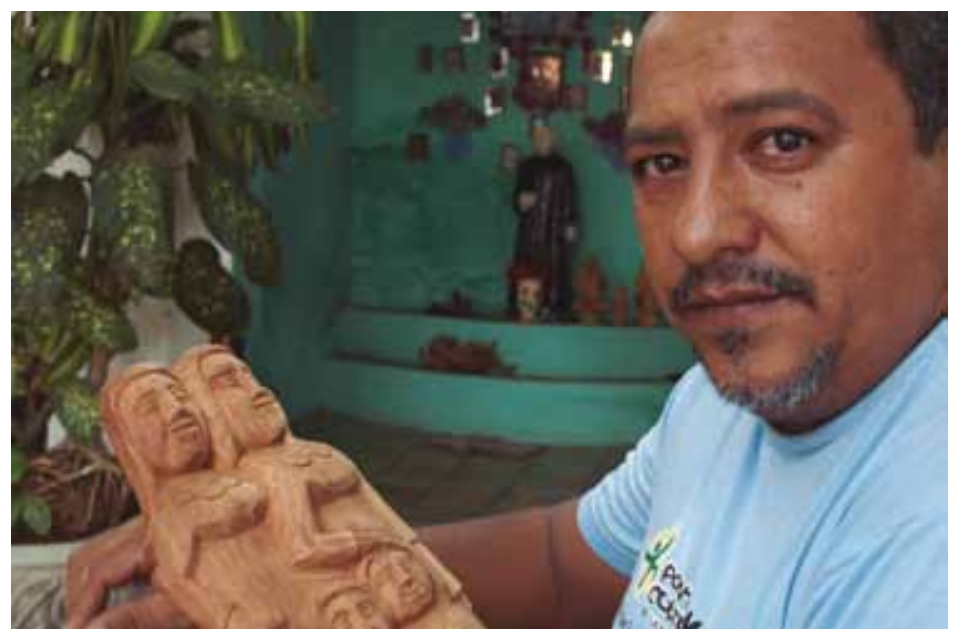

Mundinha deixa, aos 89 anos, algumas rimas escritas de seu cordel:

"A chuva que cai no chão para molhar o torrão,

é a linda Juazeiro do Padim Ciço Romão; a vida de meu Padim dá gosto de a gente ver, sentado em sua mesinha continua a escrever; e na sala de jantar tem café para você, porque ele e os amigos não irão se aborrecer;

lá no quarto suas vestes e sua cama também, mas ele dorme na rede demonstra estar muito bem;

o nosso humilde pastor foi homem forte e de fé,

por isso é que Juazeiro vai continuar de pé”.

\section{DAR O PRIMEIRO PASSO}

O Padre Cícero Romão Batista (Crato, 1844/Juazeiro do Norte, 1934) foi ordenado, em 1870, no seminário da Prainha em Fortaleza - sua formação foi junto aos padres salesianos. Quando capelão em Juazeiro do Norte, ponto de encontro tradicional dos tro- 
peiros, o lugarejo ganhou fama nacional pela hóstia tornada sangue na Sexta-feira Santa (dia 5 de março de 1889), quando da comunhão da beata Maria de Araújo. Excomungado pelo milagre eucarístico, Padre Cícero viajou a Roma, em 1898, mas logo em seguida foi reconsiderado e voltou a celebrar missa. E, assim, reuniu força política para criar o município e assumir o cargo de prefeito de Juazeiro do Norte, em 1911. Perseguido politicamente, o presidente do Ceará Franco Rebelo o demitiu. Mas Padre Cícero convocou o povo para cercar Juazeiro do Norte de trincheiras e muralhas em defesa da vila que as forças governistas queriam arrancar. Em 1926 foi eleito deputado federal, mas não assumiu o cargo. Primeiro porque a catarata lhe anuviava a vista, embranquecendo o azul brilhante de seus olhos. Segundo porque não podia deixar o sertão e migrar para o Rio de Janeiro.

Apesar de ter sido suspenso da ordem por duas vezes, nunca rompeu com a Igreja Católica. Abençoava e remediava os que o procuravam e desencadeou romarias. Deixou como inspiração para a cidade imagens, agregadas ao seu ser, que falam da fé: o cajado e a Bíblia. No Ceará, o termo "aracati", que vem da língua dos índios cariris, significa o vento bom que chega com hora marcada para refrescar o sertão. Sempre procurou orar e lutar pela gente simples que, segundo ele, "não sabe o que faz e nem vê onde marcha".

Um trecho da carta do Padre Cícero ao senador Epitácio Pessoa, em 3 de dezembro de 1927, sintetiza a luta e o poder desse vigário-político. Evidencia também a força da Igreja Católica, junto ao Estado, como pilar da estrutura de poder. "Não só como brasilei-

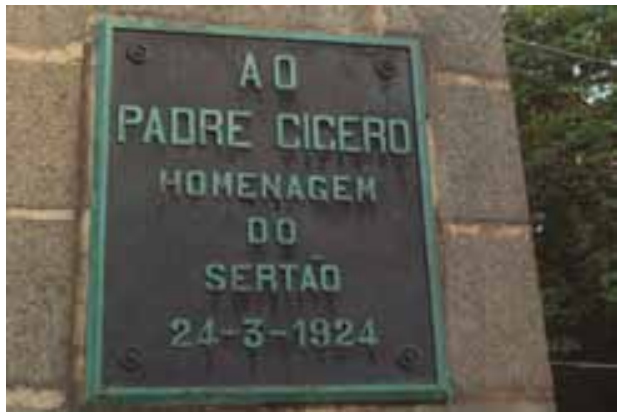

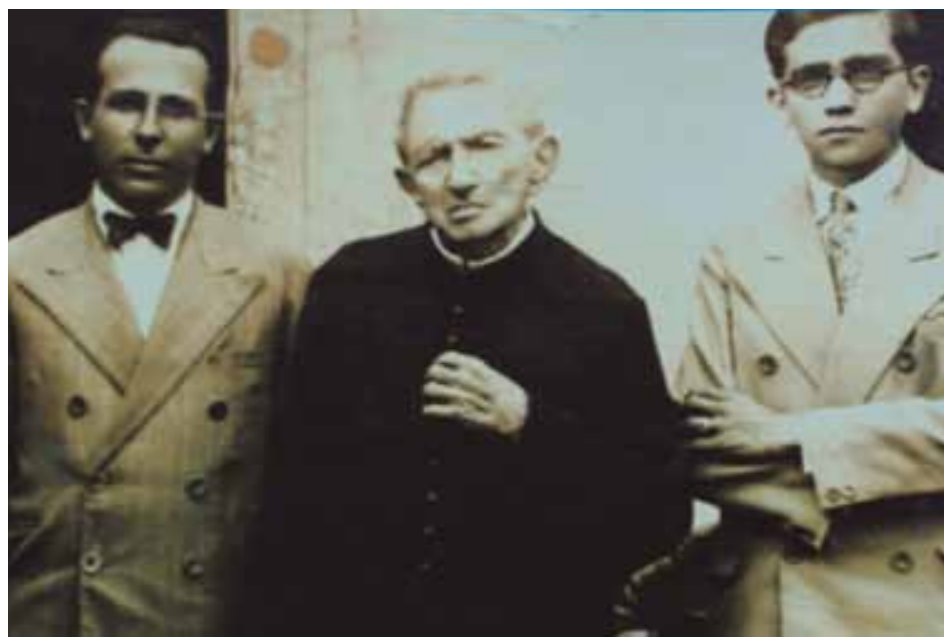

ro, porém também como político que veio do Império para o Regime Republicano, ao qual tenho servido sem desfalecimento, e ainda principalmente como sacerdote católico que deseja uma pátria forte e unida."

$\mathrm{Na}$ entrevista concedida, em 1931, aos jornalistas Paulo Sarasate e Alpheu Aboim, do jornal O Povo, de Fortaleza, Padre Cícero afirmou ser "mais seguro obedecer a Deus do que aos homens". E criticou a "perseguição aos seus semelhantes impunemente", portanto sempre incitou os sertanejos a arriscarem o primeiro passo. "Eu desejo que os novos governantes sejam sobretudo adminis-

\section{A fé cega do pároco que não virou as costas às possibilidades do sertão}

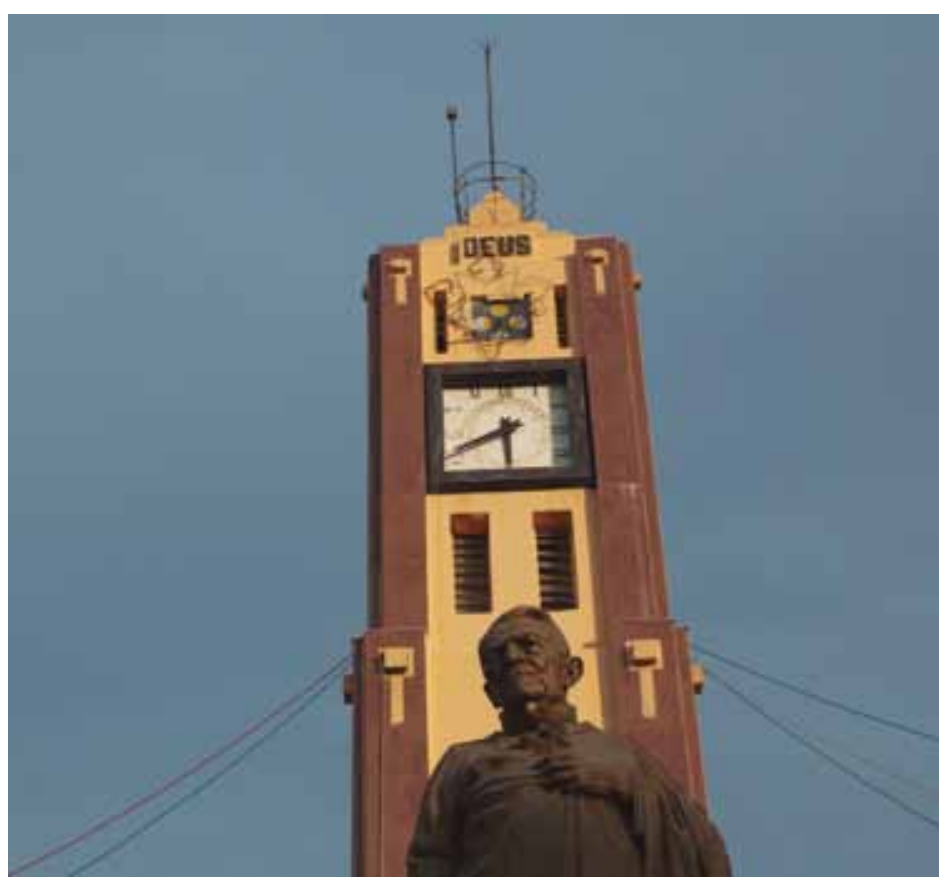




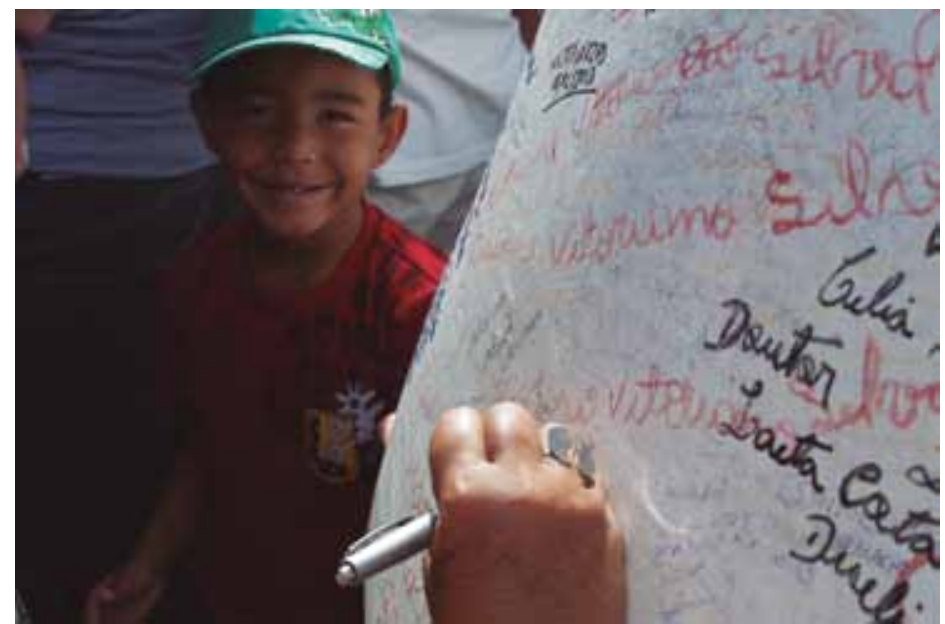

Mensagens do tempo, apesar da imaginada imobilidade tradores e não donos de uma grande fazenda, como vinha acontecendo até agora. Que a nação os faça, os eleja zeladores e defensores da Pátria e do povo e não senhores de uma senzala, para venderem-na aos pedaços a quem mais der".

\section{ENTRE TARTARUGAS E DINOSSAUROS}

Nessa região inóspita e mágica, onde havia no passado longínquo florestas tropicais, há dois locais que valem ser visitados pela importância arqueológica. O primeiro é a Fundação Casa Grande - Memorial do Homem Kariri, organização não governamental e cultural criada em 1992, com sede em Nova Olinda (CE). Sua fundação se deu a partir da restauração da casa da Fazenda Tapera, acolhendo acervo lítico (pilão, machado), cerâmico (cachimbo, tigela, urna funerária) e pintura rupestre de sítios localizados na Chapada do Araripe -, ainda hoje um refúgio verde na ari- dez do sertão. As peças pertencentes a esse acervo foram encontradas em descobertas fortuitas e doadas para formar uma coleção de referência, que contribui para socializar a ciência, a cultura e o meio ambiente.

O segundo é o Museu de Paleontologia da Universidade Regional do Cariri (Urca), em Santana do Cariri (CE), que possui coleção paleontológica - objetos entre 150 e 90 milhões de anos - composta por grupos de fauna e flora (troncos, flores, raízes, folhas, sementes), invertebrados (aranhas, escorpiões, baratas, libélulas, cigarras, mosquitos) e vertebrados (peixes, tartarugas, lagartos, crocodilos, dinossauros, pterossauros). O Museu tem o intuito de acolher, restaurar e conservar um patrimônio natural de singela beleza e importância científica, educativa e turística.

As primeiras peças chegaram, em 1985, para preservar os achados paleontológicos da região. Em 1991, o Museu foi incorporado à Urca, passando a integrar a sua estrutura acadêmica como núcleo de ensino, pesquisa e extensão. Vale destacar que, em 2006, o Geopark Araripe foi reconhecido, sob os auspícios da Unesco, como o primeiro geoparque das Américas detentor de uma das maiores jazidas fossilíferas do período cretáceo (aflorada a céu aberto nos arredores da Chapada do Araripe, com área aproximada de $3.796 \mathrm{~km}^{2}$ ).

\section{NO ESPAÇO DO SAGRADO}

A paisagem das verdes serras coabita com a monotonia infinda do semiárido, envolta por um messianismo identificado com o fanatismo religioso, que faz evocar $\mathrm{Os} \mathrm{Ser}$ -
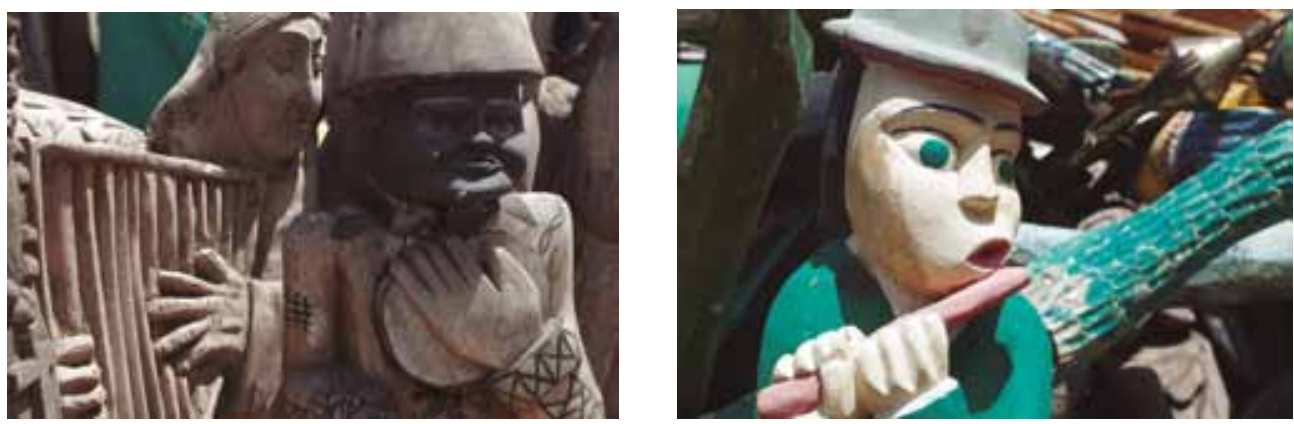


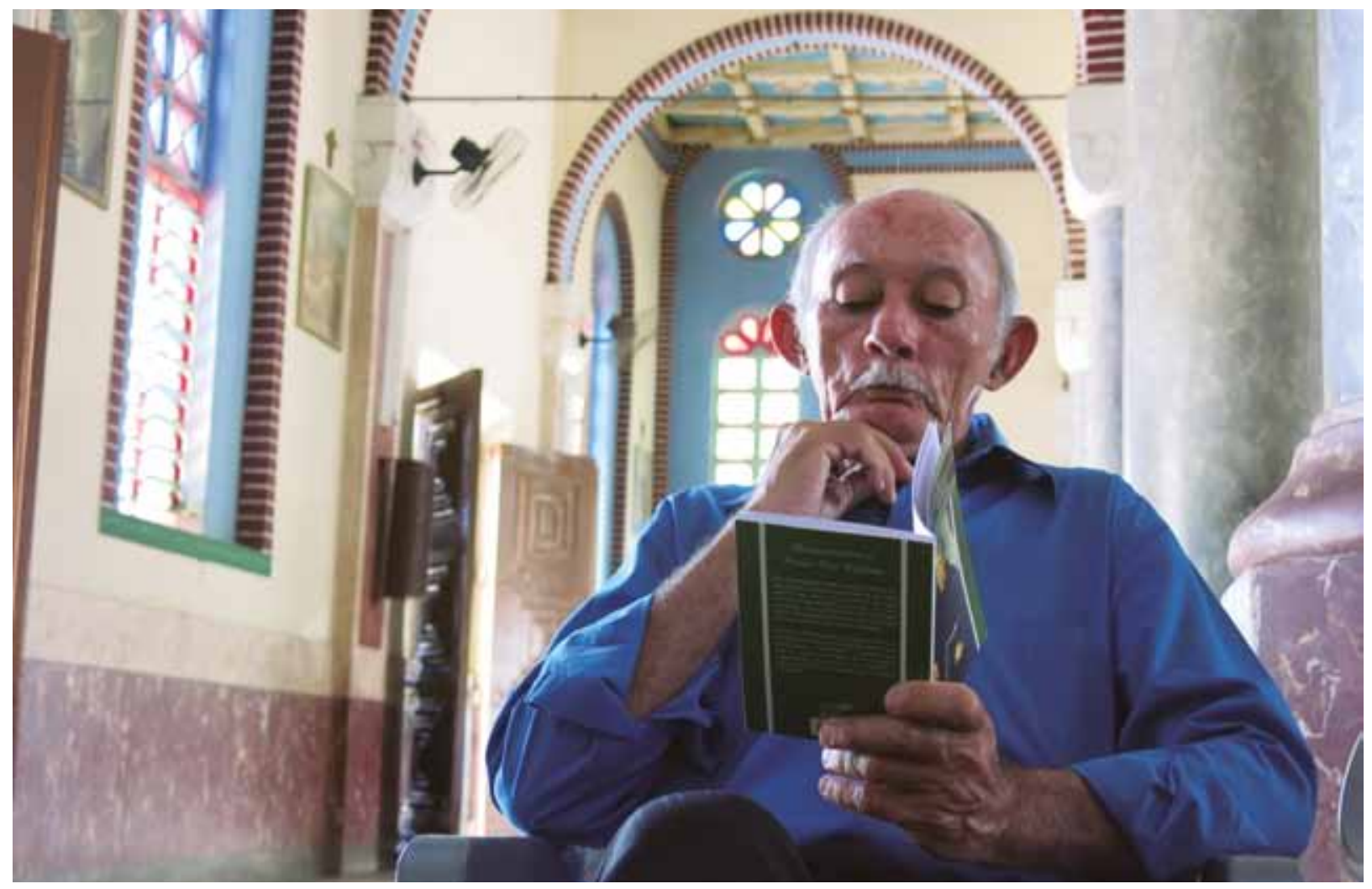

tões de Euclides da Cunha. Nessa geografia, Cícero Romão Batista (Padim Ciço) figura como clássico inconteste do repertório histórico cultural do Nordeste ao lado de Antônio Vicente Mendes Maciel (Conselheiro), Virgulino Ferreira da Silva (Lampião), Antônio Gonçalves da Silva (Patativa de Assaré) e Luís Gonzaga do Nascimento (Lua). Os cinco são figuras esculpidas em umburana ou cedro pelos mestres escultores e santeiros no Ponto de Cultura Popular Mestre Noza, localizado no prédio antigo da polícia militar de Juazeiro do Norte. Nessa cooperativa, os artesãos expõem sonhos e fantasias criados com goiva, formão e martelo (sem o uso do

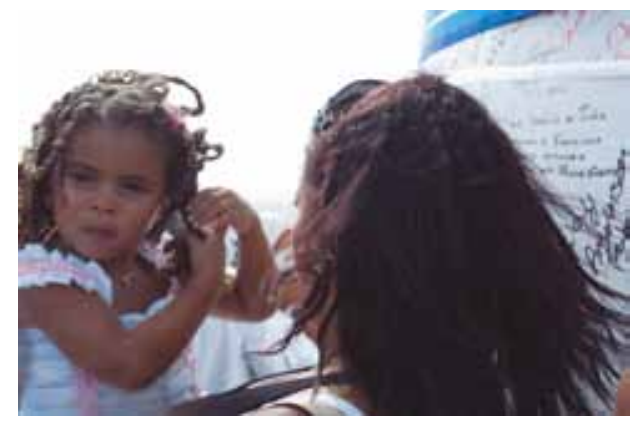

esquadro), difundindo a produção artesanal em madeira da região.

Há também o inventivo Espedito Veloso Carvalho, que confecciona roupas de vaqueiro há sessenta anos. Quente e silenciosa é Nova Olinda (CE), cidade do sertão do Cariri, onde fica seu ateliê, conhecido internacionalmente. Espedito Seleiro, seguindo a tradição familiar, fez as roupas de Luís Gonzaga (o rei do baião), nascido ali ao lado, em Exu (CE). E seu pai confeccionou o gibão de Lampião, de Maria Bonita e de todo o seu bando. O mestre-artesão descreve, rodeado pelos filhos e netos, a sua prática antiga de preparar a pele da vaca a partir

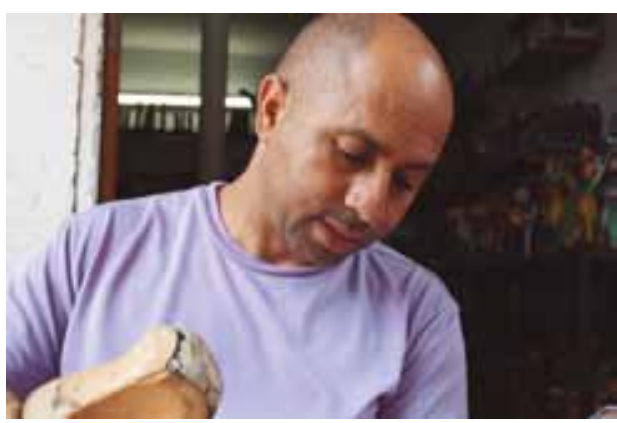

O sertanejo faz da jornada diária uma peregrinação 


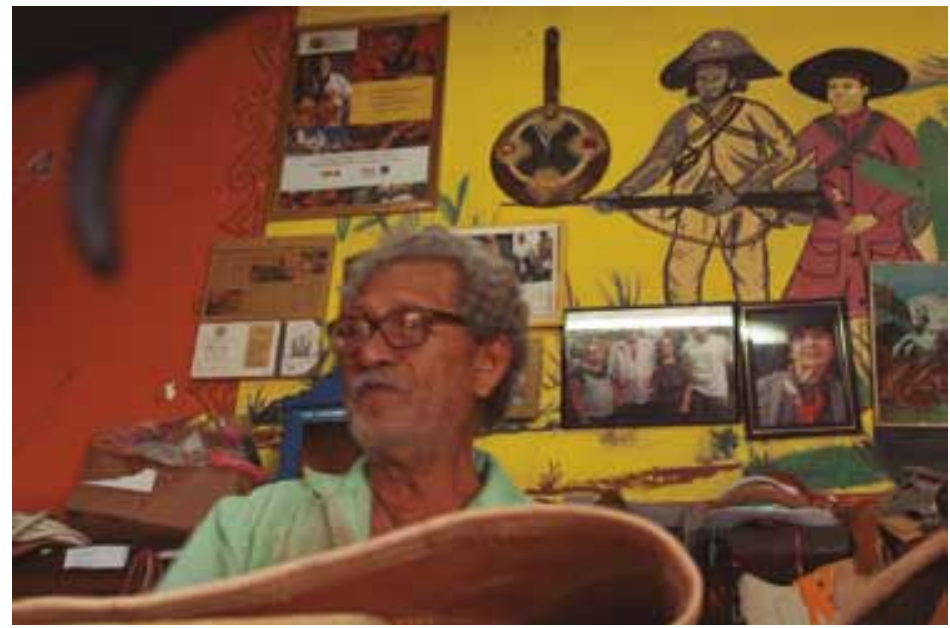

Espedito Seleiro com imagem de Lampião e Maria Bonita ao fundo de inúmeros banhos e secagens. Assim, ele pode confeccionar à mão, em couro legítimo, algibeiras, perneiras, gibões, selas, luvas, bolsas, sapatos, chapéus e demais peças para o arreio do cavalo. No entanto, com a chegada do automóvel e do asfalto, o cavalo e a atividade de vaqueiro desapareceram do sertão e migraram para o teatro, a música, a dança, o cinema e a televisão. Qual seria a nova identidade do sertanejo?

Seleiro conta que o bando de Lampião roubava os peregrinos que vinham visitar $\mathrm{Pa}$ dre Cícero em Juazeiro do Norte. Mas Padre Cícero, fazendo uso de sua sinceridade, pede a Lampião para evitar o assalto aos romeiros.
Estes, então, para serem reconhecidos, passam a transitar com um tipo de rosário identificador. Cada um a seu modo - Conselheiro, Padre Cícero, Lampião, Patativa e Luís Gonzaga - foi revolucionário de seu tempo. E todos disseminaram a sua doutrina criativa na luta contra o anticristo, considerado por eles como o diabo, o cão, o demônio ou o satanás. Fazem lembrar os vaqueiros encorajados de Grande Sertão: Veredas na narrativa de João Guimarães Rosa (1956). "Esses homens! Todos puxavam o mundo para si, para o concertar consertado. Mas cada um só vê e entende as coisas dum seu modo".

O sociólogo José de Souza Martins afirma que, tradicionalmente, a Igreja Católica no Brasil "abrigou a causa dos posseiros e dos trabalhadores rurais, alcançados pela onda de desenraizamentos e miséria decorrentes de uma política fundiária perversa". Acostumados a uma liderança poderosa e mítica de carne e osso, os sertanejos foram alavancados por Padre Cícero a trabalhar como se a morte nunca pudesse chegar, e a orar como se o fim da vida estivesse próximo. No entrecruzamento entre o poderio político e a alma de profeta, seu recado cotidiano foi tanto pelos pobres de bens materiais como pelos pobres de espírito.

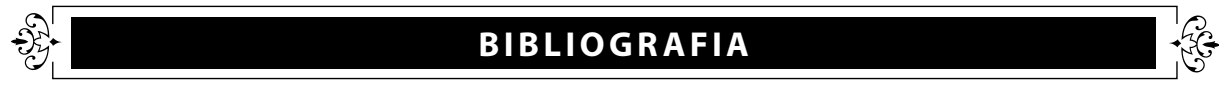

ABOIM, A.; SARASATE, P. "Entrevista com o Padre Cícero em Sua Casa”, in O Povo.

Fortaleza, fevereiro de 1931.

CAMPBELL, Joseph. O Poder do Mito. São Paulo, Palas Athena, 1990.

CUNHA, Euclides. Os Sertões: Campanha de Canudos. Cotia, Ateliê Editorial, 2009.

MARTINS, José de Souza. "De Volta ao Sagrado", in O Estado de S. Paulo. São Paulo,

17/3/2013, p. J5.

MEDEIROS, Gutemberg. Depoimento pela Internet, 16 de janeiro de 2013.

MUSEU DE PALEONTOLOGIA da Universidade Regional do Cariri. Exposição Permanente.

Santana do Cariri (CE).

MUSEU PADRE CÍCERO. Exposição Permanente. Juazeiro do Norte (CE).

ROSA, João Guimarães. Grande Sertão: Veredas. Rio de Janeiro, Nova Fronteira, 2008.

SILVA, Raimunda Tavares da. Juazeiro Rumo ao Centenário: 1911/2011. Juazeiro do Norte,

Literatura de Cordel, 2011.

VERDE, Rosiane Lima. Catálogo Fundação Casa Grande - Memorial do Homem Kariri. Nova

Olinda, 2006. 